\title{
Heavy metal chemistry in soils received long-term application of organic wastes
}

\author{
Soon-Ik Kwon ${ }^{1}$, Yeon-Ah Jang ${ }^{1}$, Kye-Hoon Kim ${ }^{2}$, Goo-Bok Jung ${ }^{1}$, Min-Kyeong Kim ${ }^{1}$, \\ Hae Hwang $^{1}$, Mi-Jin Chae ${ }^{1}$, Seung-Chang Hong ${ }^{1}$, Kyu-Ho So ${ }^{1}$, Sun-Gang Yun ${ }^{1}$, \\ Kwon-Rae $\mathrm{Kim}^{3^{*}}$ \\ ${ }^{1}$ National Academy of Agricultural Science (NAAS), RDA, Suwon, South Korea; ${ }^{*}$ Corresponding Author: kimkr419@gntech.ac.kr \\ ${ }^{2}$ The University of Seoul, Seoul, South Korea \\ ${ }^{3}$ Gyeongnam National University of Science and Technology, Jinju, South Korea
}

Received 25 September 2012; revised 27 October 2012; accepted 7 November 2012

\section{ABSTRACT}

This study was carried out to understand the long-term effect of organic waste treatment on the fate of heavy metals originated from the organic wastes, together with examination of changes in soil properties. For this, the soils received three different organic wastes (municipal sewage sludge, alcohol fermentation processing sludge, pig manure compost) in three different rates $(12.5,25,50$ ton/ha/yr) for 7 years (1994 2000) were used. To see the long-term effect, plant growth study and soil examination were conducted twice in 2000 and 2010, respectively. There was no additional treatment of organic wastes for post ten years after ceasing organic waste treatment for seven years. Soil examination conducted in $\mathbf{2 0 1 0}$ showed decreases in soil pH, EC, total nitrogen, organic matter, available phosphorus, exchangeable cations and heavy metal contents in all soils received organic wastes compared to the results obtained in $\mathbf{2 0 0 0 .}$ Speciation of heavy metals in soil through sequential extraction showed that organically bound $\mathrm{Cu}$ was the dominant species in all treatment and exchangeable $\mathrm{Cu}$ was increased in the plots treated with municipal sewage sludge and alcohol fermentation processing sludge. organically bound $\mathrm{Ni}$ increased from $25 \%-30 \%$ to $32 \%$ 45\% in 2010 in all treatment while $\mathrm{Pb}$ showed increase in carbonate form in all treatments. $\mathrm{Zn}$ existed mainly as sulfide and residual forms, showing increases in organically bound form in all treatment during post ten years.

Keywords: Heavy Metal; Long-Term Application; Organic Wastes; Sequential Extraction

\section{INTRODUCTION}

Generation of wastes along with industrialization and urbanization of the society has been elevated and treatment of the wastes in safe manner is challenging task of human for the sustainable life in this planet. Recently, social agreement for reusing the wastes as resources has been made and many researches were conducted. In particular, organic wastes defined as wastes containing $>40 \%$ organic materials such as municipal solid wastes and livestock wastes have been studied intensively to validate whether they are able to be used as alternative nutrient sources for crop plants [1]. Urine and fecal-, food-, and municipal solid-wastes are included and the amount of organic wastes generated has been increasing due to ever increased population. To date, landfill, incineration, dumping to the ocean has been mainly used to treat these wastes in addition to recycling them as resources [2] but as dumping to the ocean is banded from 2012, all the wastes must be treated in the land. In this circumstance, application of the organic wastes to agricultural land has been attracted to the governors as alternative way to treat wastes, in a mean while the soil physicochemical properties can be improved due to the organic substance and nutrients embed in the organic wastes. Epstein et al. (1976) and Smith (1996) reported that organic wastes treatment to soils induced soil amending effects by increasing water holding capacity, porosity, soil $\mathrm{pH}$, cation exchange capacity (CEC), and soil aggregate, and by decreasing soil bulk density $[3,4]$. Despite such beneficial effects of the organic wastes to soils, actual treatment of the organic wastes has been limited mainly due to possibly contained hazardous substances such as heavy metals [5]. Nicholson et al. (1997) and Zhao et al. (1997) also reported that the elevated concentrations of heavy metals in the organic wastes are limiting factors for recycling the organic wastes in agricultural soils $[6,7]$. The heavy metal originated from the 
organic wastes can be accumulated in the soils eventually resulting in detrimental effects on crop plant performance and human health. Therefore, excessive application of the organic wastes was alerted and many researches were conducted to estimate the dose amount of organic waste to agricultural soils to avoid the accumulation of heavy metals in soils $[8,9]$. Also, to minimize the input of heavy metals to agricultural soils through organic wastes application, the standard guideline values of those metals in organic wastes has been legislated in Korean Fertilizer Management Act [10]. Despite these efforts to retard metal accumulation in soils, gradual increase of metal concentration in soils may occur by the delivered heavy metal ions through organic wastes even if the concentration of heavy metals in those organic wastes are below the guideline values. Therefore better understanding of the fate and chemistry of metal ions in soils originated from the organic wastes is required for developing advanced management protocol.

The current study was conducted to understand the changes in soil properties and heavy metal chemistry in field soils received long-term application of three different organic wastes (municipal sewage sludge, alcohol fermentation processing sludge, and pig manure compost).

\section{METHODS AND MATERIALS}

\subsection{Treatment of Organic Wastes}

For organic wastes treatment, 30 field plots $(1 \times 1 \times 1$ $\mathrm{m}^{3}$ ) were constructed using concrete retaining walls and each plot was filled with cultivated upland soil after homogenization. The soils used for experimental plot preparation was Samgak series (coarse loamy, mesic family of Typic Distrochrepts) collected in Yeogi mountain, Suwon. The soils collected were sieved through $5 \mathrm{~mm}$ sieve prior to be used for filling the prepared plots. The soil was sandy loam with $\mathrm{pH} 4.85$ containing around $1 \%$ organic matter. The concentrations of total nitrogen, available phosphorous and heavy metals were lower than the average values of the Korean cultivated upland soils.

Treatment of organic wastes to each plot soil was initiated in 1994 at three different rates of 12.5, 25, and 50 ton/ha/year and continued for another successive seven years till 2000 at the same treatment rate. The introduced organic wastes were municipal sewage sludge (MSS), alcohol fermentation processing sludge (FS), and pig manure compost (PMC). For comparison, chemical fertilizer treatment plot $\left(234 \mathrm{~kg} \mathrm{~N} / \mathrm{ha}, 51 \mathrm{~kg} \mathrm{P}_{2} \mathrm{O}_{5} / \mathrm{ha}\right.$, and 81 $\mathrm{kg} \mathrm{K}_{2} \mathrm{O} / \mathrm{ha}$ ) were included and all the treatments were carried out in triplicates including control (no application of organic wastes and chemical fertilizer). The chemical properties of organic wastes used were summarized in Table 1.
Table 1. Selected physicochemical properties and trace metal concentrations of the organic wastes used in this study.

\begin{tabular}{cccc}
\hline & MSS & AFS & PMC \\
\hline $\mathrm{pH}(1: 5)$ & 6.7 & 7.1 & 8.1 \\
$\mathrm{EC}(\mathrm{dS} / \mathrm{m})$ & 42.6 & 51.8 & 60.5 \\
Organic matter $(\mathrm{g} / \mathrm{kg})$ & 559 & 788 & 707 \\
Total nitrogen $(\mathrm{g} / \mathrm{kg})$ & 34.3 & 75.1 & 26.0 \\
$\mathrm{P}_{2} \mathrm{O}_{5}(\mathrm{~g} / \mathrm{kg})$ & 4.61 & 40.8 & 60.7 \\
$\mathrm{Cations}(\mathrm{cmol} / \mathrm{kg})$ & & & \\
$\mathrm{Ca}$ & 0.38 & 0.15 & 0.35 \\
$\mathrm{~K}$ & 0.13 & 0.15 & 0.36 \\
$\mathrm{Mg}$ & 0.02 & 0.25 & 0.14 \\
$\mathrm{Trace} \mathrm{metal}(\mathrm{mg} / \mathrm{kg})$ & & & \\
$\mathrm{Cu}$ & 134.4 & 177.9 & 576.8 \\
$\mathrm{~Pb}$ & 19.7 & 15.1 & 3.7 \\
$\mathrm{Zn}$ & 792.9 & 363.2 & 782.7 \\
\hline
\end{tabular}

MSS = Municipal Sewage Sludge; AFS = Alcohol Fermentation Processing Sludge AFS; PMC = Pig Manure Compost.

Following the application for seven years, the soils in the plots were allowed to be managed by the conventional cultivation manner for ten years by 2010 without any further organic wastes applications. During this period, chemical fertilizers were applied for crop plant cultivations (bean, Chinese cabbage, reddish etc.).

\subsection{Soil Sampling and Analysis}

Soil sampling was carried out in March 1994 before application of organic wastes and in October 2000 and 2010 after harvesting crop plant. Five discrete soil samples collected using $\varnothing 5 \mathrm{~cm}$ augur sampler from each plot were composited to make a representative soil sample for each plot. The collected soils were thoroughly mixed, air-dried, sieved using $2 \mathrm{~mm}$ stainless steel sieve.

Soil $\mathrm{pH}$ and EC were determined on a 1:5 soil:water $(\mathrm{w} / \mathrm{v})$ suspension using a combination $\mathrm{pH}-\mathrm{EC}$ meter (Thermo Orion 4 Star Plus, USA) following $1 \mathrm{~h}$ equilibration. Soil organic matter content was determined using the Walkely-Black method while organic matter contents of the organic waste were determined using loss on ignition at $550^{\circ} \mathrm{C}$ [11]. Total-N in soil and organic wastes were determined by the Kjeldahl digestion method followed by titration using $0.5 \mathrm{~N} \mathrm{FeSO}_{4}$ [12]. Soil texture was determined using a micro-pipette method [13]. Cation exchange capacity and exchangeable cations in soils were determined using a $1 \mathrm{M} \mathrm{CH}_{3} \mathrm{COOH}(\mathrm{pH}$ 7.0) extraction method [14]. 
Heavy metal concentrations in soils and organic wastes were determined by inductively coupled plasma-optical emission spectrometer (ICP-OES; GBC Integra XL, Australia) following acidic digestion. While soils $(0.5 \mathrm{~g},<2$ $\mathrm{mm})$ were digested with aqua regia $(10 \mathrm{ml})$ using a micro-wave digestion oven (MARS5, CEM), organic wastes $(0.5 \mathrm{~g})$ were digested with concentrated $\mathrm{HNO}_{3}(15 \mathrm{ml})$ using a block digester (Buchi digest system K-437, Buchi labortechnik, Switzerland) [15]. Each batch of digested soil samples also included a certified reference material (Montana Soil SRM2711, National Institute of Standards and Technology) and blanks to validate the digestion procedure. Each batch of digested organic waste samples also included blanks and spiked samples at a rate of $5 \%$ to ensure quality control. The digested suspensions of soils and organic wastes were filtered through $0.45 \mu \mathrm{m}$ disposable filters and trace metal concentrations in filtrate determined using ICP. Hereafter, aqua regia acid extractable concentrations are referred to simply as the total metal concentration in the soil. Available and/or soluble metal pools in the soil were assessed using the $0.1 \mathrm{~N} \mathrm{HCl}$ extraction method [16]. For this, soil $(10 \mathrm{~g},<2$ $\mathrm{mm})$ was shaken for one hour with $0.1 \mathrm{~N} \mathrm{HCl}(50 \mathrm{~mL})$ in a $250 \mathrm{~mL}$ Erlenmeyer flask. The soil suspension was subsequently filtered through $0.45 \mu \mathrm{m}$ disposable filters and the trace metal concentrations in the filtrate analyzed using ICP.

In order to examine the heavy metal fraction existing in different forms in soils, sequential extraction was performed using the extraction method summarized in Table 2 [17]. The heavy metal fractions included soluble(F1), exchangeable-(F2), organically bound-(F3), carbonate-(F4), and sulfide/residual-forms (F5). The extracted solution was filtered through $0.45 \mu \mathrm{m}$ disposable filters followed by analysis of heavy metals in the filtrate using ICP.

\section{RESULTS AND DISCUSSION}

\subsection{Changes in Soil Properties}

Soil $\mathrm{pH}$ of all the experimental plots determined ten years after ceasing organic waste application ranged 3.6 4.9 being declined compared to those determined in 2000 (Table 3). Among the organic wastes, FS appeared to decline soil $\mathrm{pH}$ the most at 3.6 - 4.2. PMC treated soil showed increased soil $\mathrm{pH}$ up to $6.0-7.0$ during the period when the soil received the annual application of PMC from 1994 to 2000 and then the $\mathrm{pH}$ declined back to below 5.0 with no application of PMC for post ten years. Soil $\mathrm{pH}$ is one of the most important environmental factors governing heavy metal chemistry in soils and hence it was expected that the heavy metals dynamics would be affected by the changes of soil $\mathrm{pH}$ along with different organic wastes treatment.
Table 2. Chemical extraction scheme for heavy metal fractionation in soils.

\begin{tabular}{cccc}
\hline Fraction & Extractant & Shaking time & Metal species \\
\hline F1 & $\mathrm{H}_{2} \mathrm{O}$ & $30 \mathrm{~min}$ & Water soluble \\
F2 & $0.5 \mathrm{M} \mathrm{KNO}_{3}$ & $16 \mathrm{hr}$ & $\begin{array}{c}\text { Exchangeable } \\
\text { Organically } \\
\text { bound }\end{array}$ \\
F3 & $0.5 \mathrm{M} \mathrm{NaOH}$ & $16 \mathrm{hr}$ & $6 \mathrm{hr}$. \\
F4 & $0.05 \mathrm{M} \mathrm{EDTA}$ & $\begin{array}{c}\text { Carbonate } \\
16 \mathrm{hr} \\
\left.\text { (at } 80^{\circ} \mathrm{C}\right)\end{array}$ & $\begin{array}{c}\text { Sulfide \& } \\
\text { Residual }\end{array}$ \\
F5 & $4 \mathrm{M} \mathrm{HNO}_{3}$ & &
\end{tabular}

Organic waste treatment for seven years increased electrical conductivity (EC) of the soils and the increased magnitude was proportional with the application amount appeared the biggest increase occurred with 50 ton/ha/yr treatment. For instance, 50 ton/ha/yr FS treatment showed EC value at $3.39 \mathrm{dS} / \mathrm{m}$ in 2000 and this declined down to $1.05 \mathrm{dS} / \mathrm{m}$ in 2010 . Like FS treated soils, decline of EC in 2010 compared to the values in 2000 was common for all organic waste treated soils. Despite decline of EC with time, the relatively higher EC shown with FS treatment implied that depending on the organic wastes, the application of excessive amount of organic wastes should be avoided not to experience salt damages on crop plants.

Along with organic waste treatment, the contents of organic matter, total-N, available $\mathrm{P}_{2} \mathrm{O}_{5}$ was increased and then decreased during another ten years without any more input of organic wastes. In particular, MSS and PMC increased available $P$ at the range of $558-1500$ $\mathrm{mg} / \mathrm{kg}$ and $594-1919 \mathrm{mg} / \mathrm{kg}$, respectively and the PMC treated soil appeared to be declined this value down to $356-680 \mathrm{mg} / \mathrm{kg}$ while MSS treated soil showed limited decline down to $426-1237 \mathrm{mg} / \mathrm{kg}$. This result indicated that the accumulation of available $\mathrm{P}$ in soil might be occurred with long-term application of organic waste if the application amount of organic wastes is determined based on the nitrogen concentration embedded in organic wastes, which is generally performed. Therefore, the application amount of organic wastes such as PMC and MSS should be determined based on the available P contents and any insufficient nutrients should be supplied with chemical fertilizers. The previous study conducted by Kim et al. (2000) supported this explanation [18]. In their study, total-N and available $\mathrm{P}$ increased with increase in compost application amount and from this result, they concluded that $\mathrm{P}$ accumulation would be the detrimental effect with agricultural use of compost and hence countermeasure is required. In comparison with NPK treatment, exchangeable cations were not affected much with organic waste treatment except PMC which increased $\mathrm{Ca}$ accumulation levels in soils. 
Table 3. Chemical properties in 2000 and 2010 of the soil treated in this experiment.

\begin{tabular}{|c|c|c|c|c|c|c|c|c|c|}
\hline \multirow{3}{*}{ Year } & \multirow{3}{*}{ Treatment } & \multirow{3}{*}{$\mathrm{pH}_{1: 5}$} & \multirow{2}{*}{$\mathrm{EC}_{1: 5}$} & \multirow{2}{*}{$\mathrm{T}-\mathrm{N}$} & \multirow{2}{*}{$\mathrm{OM}$} & \multirow{2}{*}{ AV.- $\mathrm{P}_{2} \mathrm{O}_{5}$} & \multicolumn{3}{|c|}{ Exchangeable } \\
\hline & & & & & & & $\mathrm{Ca}$ & K & $\mathrm{Mg}$ \\
\hline & & & $\mathrm{dS} / \mathrm{m}$ & & & $\mathrm{mg} / \mathrm{kg}$ & & $\mathrm{mol}_{\mathrm{c}} / \mathrm{kg}$ & \\
\hline \multirow{10}{*}{2000} & NPK & 5.0 & 1.22 & 1.3 & 15.6 & 343 & 0.74 & 0.56 & 0.10 \\
\hline & $\operatorname{MSS} 12.5^{\mathrm{a}}$ & 5.4 & 0.38 & 1.2 & 19.2 & 558 & 1.32 & 0.08 & 0.16 \\
\hline & MSS 25 & 4.8 & 0.68 & 1.4 & 23.5 & 907 & 0.79 & 0.09 & 0.12 \\
\hline & MSS 50 & 4.5 & 1.18 & 1.8 & 25.6 & 1500 & 0.69 & 0.10 & 0.12 \\
\hline & FS 12.5 & 4.5 & 1.01 & 2.6 & 23.9 & 366 & 0.49 & 0.09 & 0.30 \\
\hline & FS 25 & 4.2 & 1.62 & 4.3 & 39.5 & 495 & 0.52 & 0.17 & 0.43 \\
\hline & FS 50 & 4.4 & 3.39 & 8.5 & 51.3 & 765 & 0.84 & 0.50 & 1.00 \\
\hline & PMC 12.5 & 6.5 & 0.39 & 1.5 & 21.3 & 594 & 2.43 & 0.30 & 0.58 \\
\hline & PMC 25 & 6.6 & 0.62 & 2.1 & 25.2 & 1261 & 3.03 & 0.57 & 0.97 \\
\hline & PMC 50 & 6.7 & 1.00 & 3.5 & 45.6 & 1919 & 4.01 & 1.19 & 1.60 \\
\hline \multirow{10}{*}{2010} & NPK & 4.7 & 0.45 & 0.9 & 9.3 & 253 & 1.18 & 0.08 & 0.22 \\
\hline & MSS 12.5 & 4.4 & 0.50 & 1.0 & 11.7 & 426 & 0.81 & 0.05 & 0.19 \\
\hline & MSS 25 & 4.1 & 0.49 & 1.2 & 12.6 & 807 & 0.45 & 0.03 & 0.10 \\
\hline & MSS 50 & 3.9 & 0.63 & 1.4 & 14.9 & 1237 & 0.33 & 0.02 & 0.10 \\
\hline & FS 12.5 & 4.2 & 0.59 & 1.8 & 12.6 & 328 & 0.56 & 0.04 & 0.13 \\
\hline & FS 25 & 3.9 & 0.71 & 2.8 & 15.6 & 414 & 0.48 & 0.04 & 0.12 \\
\hline & FS 50 & 3.6 & 1.05 & 4.5 & 23.1 & 466 & 0.35 & 0.03 & 0.12 \\
\hline & PMC 12.5 & 4.6 & 0.45 & 1.3 & 9.4 & 356 & 1.65 & 0.08 & 0.24 \\
\hline & PMC 25 & 4.7 & 0.44 & 1.9 & 11.2 & 481 & 2.21 & 0.10 & 0.28 \\
\hline & PMC 50 & 4.9 & 0.41 & 2.3 & 13.9 & 680 & 3.59 & 0.14 & 0.41 \\
\hline
\end{tabular}

NPK: Chemical fertilizer treatment; MSS: Municipal sewage sludge; FS: Alcohol fermentation processing sludge; PMC: Pig manure compost; a. ton/ha/yr.

\subsection{Changes in Heavy Metal Contents}

In general, total concentration of heavy metals in soils with all organic waste treatments decreased during post ten years without any more input of organic wastes compared to those in 2000 (Table 4). The general decrease of total heavy metal concentration during ten years may contribute to metal uptake by crop plants and leaching through soil profile $[19,20]$. Unlike total metal concentration, changes in the $0.1 \mathrm{~N} \mathrm{HCl}$ extractable concentration were dependant on the type of heavy metals and organic wastes. There was only slight decline in 0.1 $\mathrm{N} \mathrm{HCl}$ extractable $\mathrm{Cu}$ in the soils received PMC and even increased extractable $\mathrm{Cu}$ was observed with 50 ton/ ha/yr PMC treatment despite the biggest decline in total $\mathrm{Cu}$ observed with PMC treated soil at 50 ton $/ \mathrm{ha} / \mathrm{yr}$. This might be due to $\mathrm{Cu}$ property in regard with total organic carbon (TOC) in soil solution. $\mathrm{Cu}$ extractability can be increased with elevated TOC in soil solution and TOC concentration can be increased with successive crop cultivation [20]. Total $\mathrm{Ni}$ and $\mathrm{Pb}$ concentrations decreased by $1-3 \mathrm{mg} / \mathrm{kg}$ during post ten years with all treatments as application amount increased while no significant changes in extractable $\mathrm{Ni}$ and $\mathrm{Pb}$ was observed. This little decline in total concentration and no changes in extractable concentration in $\mathrm{Ni}$ and $\mathrm{Pb}$ reflected the lower mobility of these heavy metals in soils. Both total and extractable $\mathrm{Zn}$ concentration determined in 2000 and 2010 were higher in PMC treated soils than any other organic wastes treated soils even though $\mathrm{Zn}$ concentration in the examined organic wastes were in the order of MSS $>$ PMC $>$ FS. This implied that there would be differences in extractability and mobility of $\mathrm{Zn}$ depending on the type of organic wastes.

\subsection{Heavy Metal Speciation}

For copper, organically bound form (F3) was the main species existed in the soils determined both in 2000 and 2010 with all treatments (Figure 1). This was in good agreement with the general consensus that $\mathrm{Cu}$ has high affinity to bound on the organic substances [17]. The 
Table 4. Heavy metal concentrations of the experimental soils determined in 2000 and 2010.

\begin{tabular}{|c|c|c|c|c|c|c|c|c|c|}
\hline \multirow{3}{*}{ Year } & \multirow{3}{*}{ Treatment } & \multicolumn{4}{|c|}{ Total } & \multicolumn{4}{|c|}{$0.1 \mathrm{~N} \mathrm{HCl}$ extractable } \\
\hline & & $\mathrm{Cu}$ & $\mathrm{Ni}$ & $\mathrm{Pb}$ & $\mathrm{Zn}$ & $\mathrm{Cu}$ & $\mathrm{Ni}$ & $\mathrm{Pb}$ & $\mathrm{Zn}$ \\
\hline & & \multicolumn{4}{|c|}{$\mathrm{mg} \cdot \mathrm{kg}^{-1}$} & \multicolumn{4}{|c|}{$\mathrm{mg} \cdot \mathrm{kg}^{-1}$} \\
\hline \multirow{10}{*}{2000} & NPK & 13.7 & 12.9 & 25.4 & 95.4 & 1.4 & 0.3 & 4.8 & 2.7 \\
\hline & $\operatorname{MSS} 12.5^{\mathrm{a}}$ & 19.7 & 13.7 & 26.7 & 112.9 & 5.3 & 0.2 & 6.4 & 26.4 \\
\hline & MSS 25 & 26.9 & 14.7 & 29.2 & 118.0 & 8.0 & 0.3 & 7.5 & 29.5 \\
\hline & MSS 50 & 38.9 & 14.9 & 32.8 & 127.4 & 10.8 & 0.3 & 7.2 & 27.1 \\
\hline & FS 12.5 & 23.6 & 13.1 & 23.4 & 76.9 & 5.9 & 0.3 & 4.2 & 5.1 \\
\hline & FS 25 & 33.7 & 14.1 & 25.8 & 84.2 & 9.7 & 0.4 & 3.8 & 5.7 \\
\hline & FS 50 & 51.9 & 14.8 & 28.7 & 84.7 & 16.6 & 1.0 & 1.8 & 12.4 \\
\hline & PMC 12.5 & 34.4 & 12.0 & 24.0 & 105.3 & 10.0 & 0.2 & 4.6 & 25.3 \\
\hline & PMC 25 & 55.4 & 12.4 & 24.4 & 138.7 & 13.5 & 0.4 & 3.7 & 57.0 \\
\hline & PMC 50 & 108.2 & 14.2 & 26.0 & 214.3 & 13.9 & 0.6 & 2.2 & 126.1 \\
\hline \multirow{10}{*}{2010} & NPK & 12.3 & 12.2 & 22.0 & 77.5 & 2.0 & 0.4 & 5.1 & 3.3 \\
\hline & MSS 12.5 & 17.1 & 10.6 & 24.7 & 89.3 & 4.2 & 0.2 & 5.8 & 5.2 \\
\hline & MSS 25 & 24.0 & 11.5 & 25.8 & 93.3 & 6.1 & 0.2 & 6.8 & 6.7 \\
\hline & MSS 50 & 35.9 & 12.3 & 31.0 & 98.3 & 9.1 & 0.2 & 8.1 & 7.4 \\
\hline & FS 12.5 & 19.5 & 12.7 & 23.7 & 61.7 & 4.8 & 0.2 & 4.4 & 3.7 \\
\hline & FS 25 & 26.1 & 13.4 & 23.5 & 70.4 & 6.8 & 0.3 & 3.4 & 3.2 \\
\hline & FS 50 & 42.1 & 14.1 & 25.0 & 73.1 & 11.3 & 0.2 & 1.7 & 2.5 \\
\hline & PMC 12.5 & 28.1 & 10.4 & 22.6 & 98.6 & 8.8 & 0.4 & 4.0 & 13.5 \\
\hline & PMC 25 & 46.8 & 11.4 & 23.1 & 128.4 & 13.5 & 0.4 & 3.7 & 26.1 \\
\hline & PMC 50 & 74.3 & 11.9 & 24.4 & 188.3 & 20.1 & 0.6 & 2.6 & 60.7 \\
\hline
\end{tabular}

NPK: Chemical fertilizer treatment; MSS: Municipal sewage sludge; FS: Alcohol fermentation processing sludge; PMC: Pig manure compost; a. ton/ha/yr.

soils received PMC for seven years showed no changes in the fractions of exchangeable (F2), organically bound (F3), and carbonate bound (F4) ten years after ceasing the PMC application compared to the values in 2000. In contrast, FS treated soils appeared to decline in the fraction of F3 and F4 and to increase in the fraction of F2. This implied that decrease of F3 and F4 induced the increased $\mathrm{F} 2$ fraction of $\mathrm{Cu}$ in soils.

For nickel, the species fraction in the soils received organic wastes for seven years were in the order of F5 $>$ $\mathrm{F} 3>\mathrm{F} 4>\mathrm{F} 2>\mathrm{F} 1$ in 2000 but changes in F3 and F4 were occurred during post ten years without no more input of organic wastes depending on the type of organic wastes applied (Figure 2). All experimental soils, except NPK treated soil, showed increase in F3 fraction from $23 \%-25 \%$ to $29 \%$ - $30 \%$ in particular with PMC treated soil being increased the most. In contrast, F4 fraction with NPK and MSS treated soils decreased while it was increased with FS and PMC treated soils implied that the F4 fraction was influenced by the type of organic wastes treated.

$\mathrm{Pb}$ speciation showed higher F4 fraction in both 2000 and 2010 than any other metal ions examined (Figure 3). In the previous studies conducted by Jung et al. (2000) and Yoo et al. (1995) also evidenced that EDTA extractable (F4) form was the main species of $\mathrm{Pb}$ in soil $[21,22]$. The post ten years management resulted in increase of $\mathrm{F} 4$ fraction of $\mathrm{Pb}$ in soils with all treatments while there were no significant changes in F2 and F3 fractions in soils determined in 2010 compared to 2000 soil reflecting less mobility of $\mathrm{Pb}$ in soils compared to other metal ions. Yoo et al. (1995) reported that metal mobility is likely retarded as the F3 and F4 fraction increased and hence the lower mobility of $\mathrm{Pb}$ in soil was contributed to the higher F3 fraction in soil [22].

In $\mathrm{Zn}$ fractionation, F2 fraction was the major species 

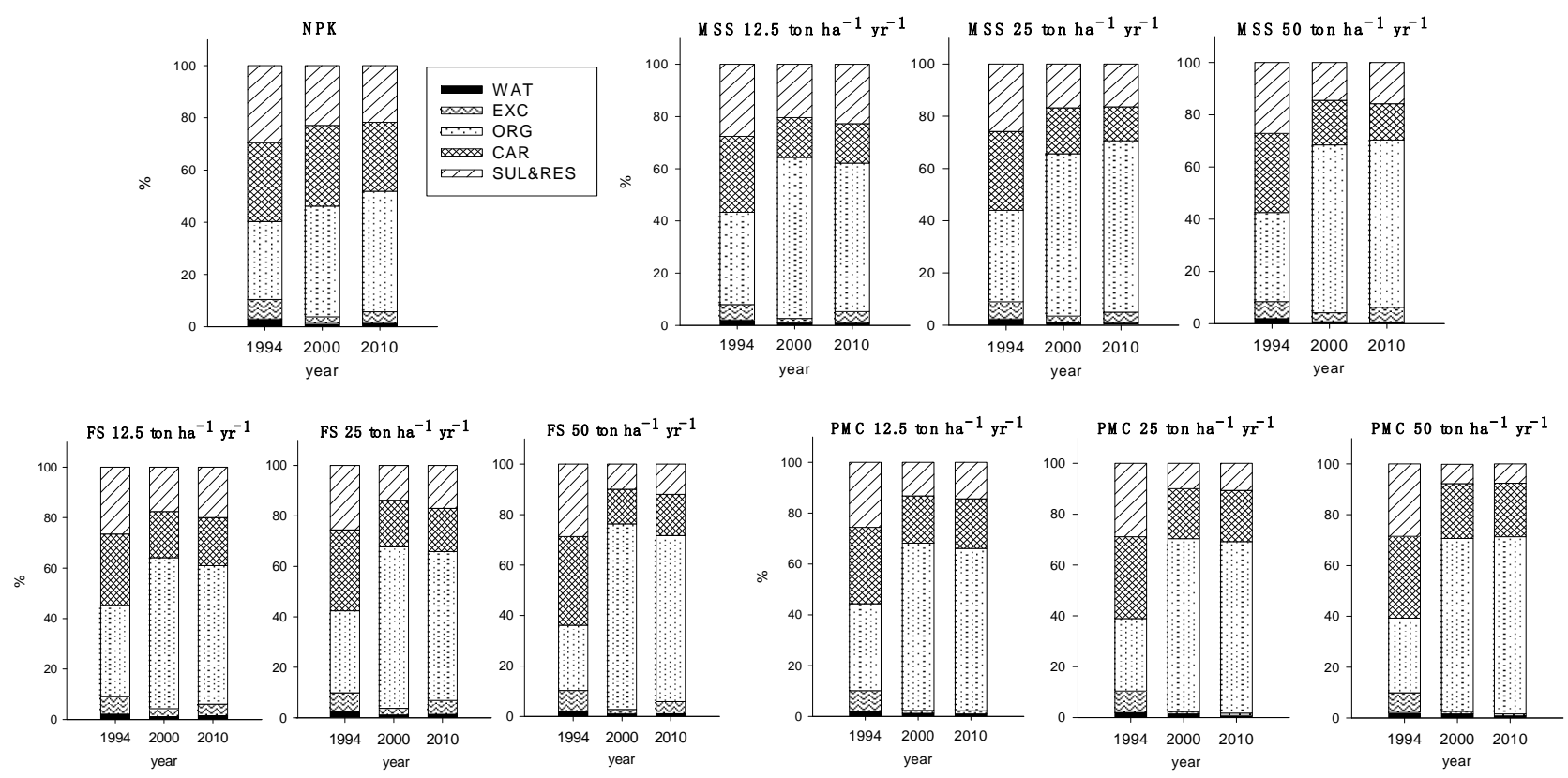

Figure 1. Fraction of $\mathrm{Cu}$ in the soils received long-term three different organic wastes applications. The values were determined in 1994, 2000 and 2010 (WAT, water soluble; EXC, exchangeable; ORG, organically bound; CAR, carbonate form; SUL\&RES, sulfide and residual forms).
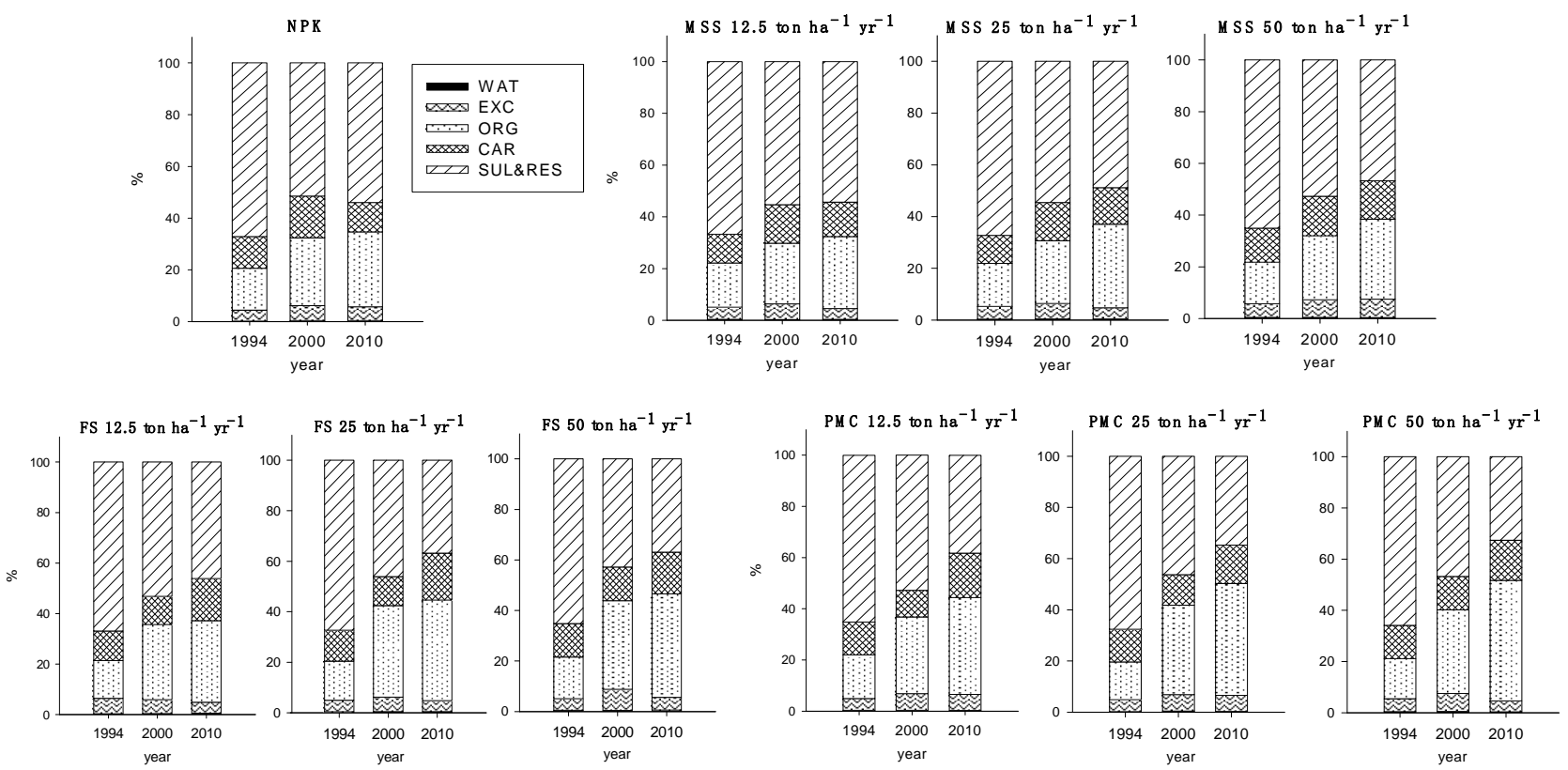

Figure 2. Fraction of Ni in the soils received long-term three different organic wastes applications. The values were determined in 1994, 2000 and 2010 (WAT, water soluble; EXC, exchangeable; ORG, organically bound; CAR, carbonate form; SUL\&RES, sulfide and residual forms).

existing in soils in both 2000 and 2010, which was agreed well with the report by Chang et al. (1984) in which exchangeable and carbonated forms of $\mathrm{Zn}$ was the most dominant species in soils received municipal solid sludge [20]. In 2000, the $\mathrm{Zn}$ fraction was in the order of F5 $>$ F4 $>$ F2 $>$ F3 $>$ F1 irrespective with the type and amount of organic wastes treated and the fractions of each species were changed during post ten years. While the organic wastes were applied for seven years, F3 fraction of $\mathrm{Zn}$ showed no significant change but this increased during post ten years in all experimental soils, in particular with FS treated soil. As a result of increased F3 fractions of Zn in FS and MSS treated soils, F2 and F4 fractions were proportionally decreased in the corre- 

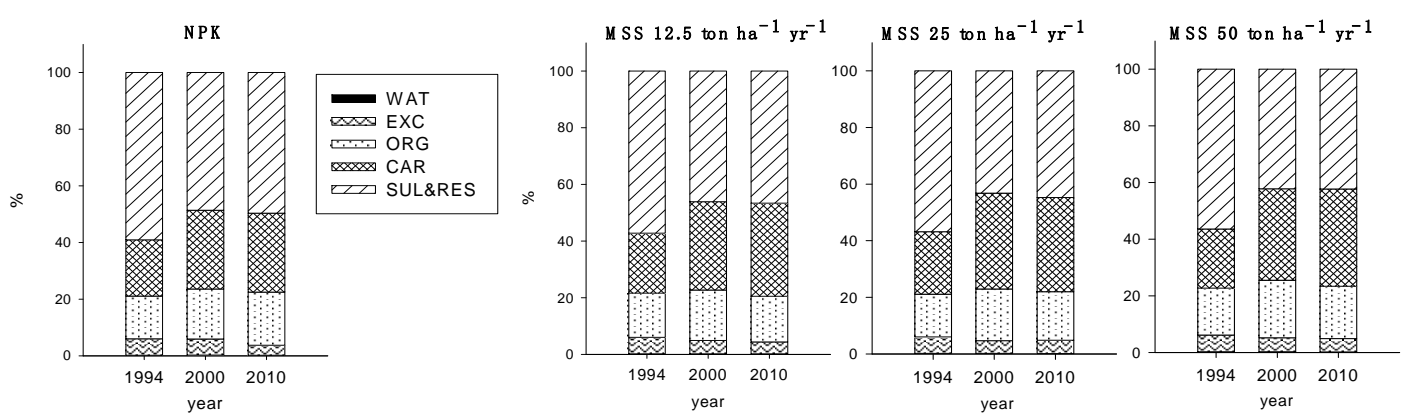

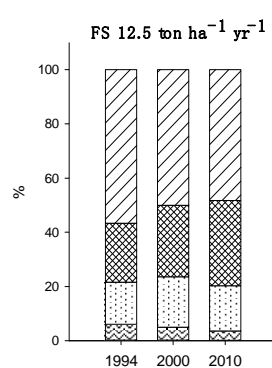

year

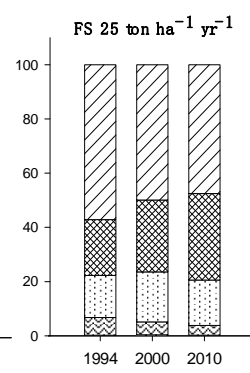

year

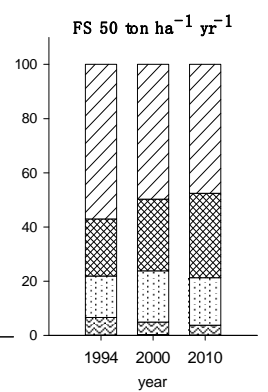

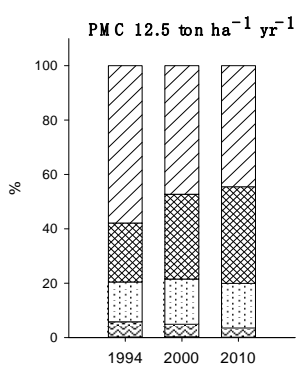

year

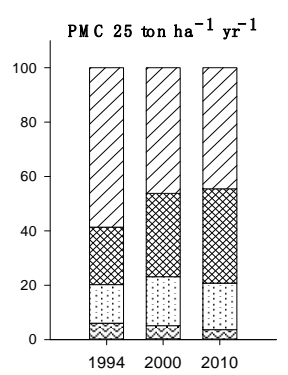

year

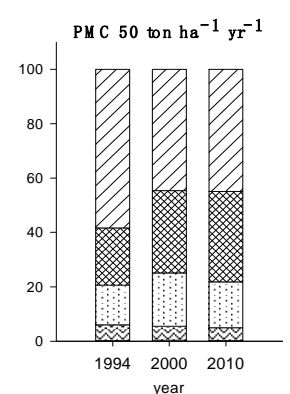

year

Figure 3. Fraction of $\mathrm{Pb}$ in the soils received long-term three different organic wastes applications. The values were determined in 1994, 2000 and 2010 (WAT, water soluble; EXC, exchangeable; ORG, organically bound; CAR, carbonate form; SUL\&RES, sulfide and residual forms).
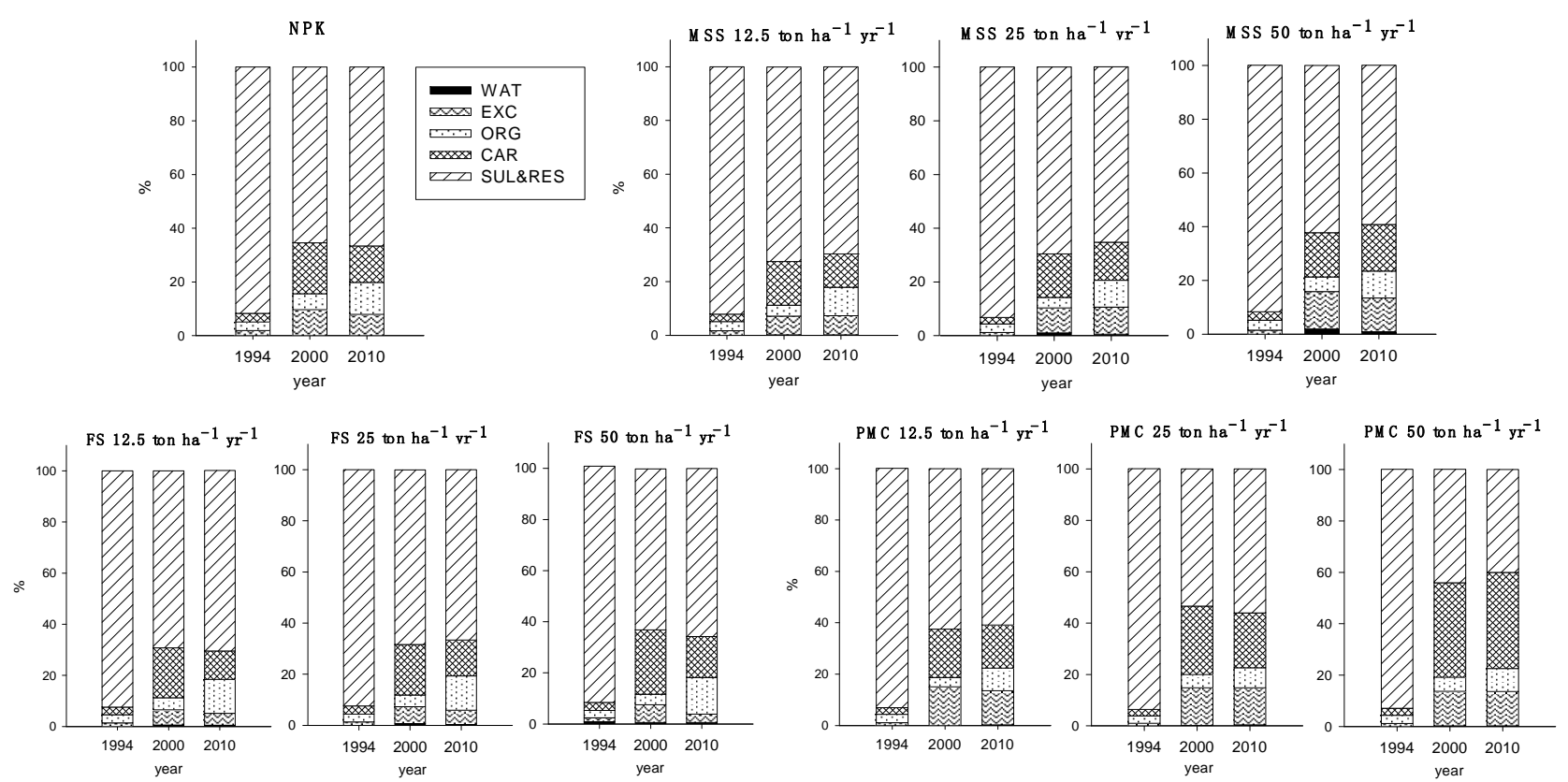

Figure 4. Fraction of $\mathrm{Zn}$ in the soils received long-term three different organic wastes applications. The values were determined in 1994, 2000 and 2010 (WAT, water soluble; EXC, exchangeable; ORG, organically bound; CAR, carbonate form; SUL\&RES, sulfide and residual forms).

sponding soils. In contrast, PMC treated soils appeared to be less in the magnitude of F3 fraction increment compared to other organic waste treated soils while increment of F4 fraction with PMC treatment was noticeable. Also, F2 fraction of $\mathrm{Zn}$ in the PMC treated soil showed higher value as it was in 2000 .

\section{SUMMARY}

The current study was conducted to examine the changes in soil properties and heavy metal chemistry in the soils received organic wastes (municipal sewage sludge, MSS; alcohol fermentation processing sludge, FS; pig manure compost, $\mathrm{PMC}$ ) for seven years followed by 
no more input of organic wastes for another post ten years. Soil $\mathrm{pH}, \mathrm{EC}$, total-N, organic matter, available-P, exchangeable cations, total heavy metal concentrations decreased during post ten years. Heavy metal speciation showed increase in exchangeable $\mathrm{Cu}$ with MSS and FS treated soils which was contributed to decline in organically bound and carbonate $\mathrm{Cu}$. In contrast with $\mathrm{Cu}$, organically bound $\mathrm{Ni}$ was increased from $25 \%$ - 30\% to $32 \%-45 \%$ during post ten years. For $\mathrm{Pb}$, carbonated $\mathrm{Pb}$ increased in all experimental soils during post ten years, while there were no significant changes in exchangeable and organically bound $\mathrm{Pb}$ reflecting low mobility of $\mathrm{Pb}$ in soil. Unlike other metal ions, Zn showed increase in organically bound fraction which induced decrease of exchangeable and carbonated $\mathrm{Zn}$ fractions in the MSS and FS treated soils.

\section{ACKNOWLEDGEMENTS}

This study was carried out with the support of "Research Program for Agricultural Science \& Technology Development (Project No. PJ008566012012)", National Academy of Agricultural Science, Rural Development Administration, Republic of Korea and this work was also supported by Gyeongnam National University of Science and Technology Grant.

\section{REFERENCES}

[1] NIER (2004) Resource recycling of waste management status and prospects. National Institute of Environmental Research, Chon, 129-153.

[2] NIAST (2003) Agricultural utilization of organic wastes and its environmental risk assessments. National Institute of Agricultural Science and Technology, RDA, Suwon, 49-103.

[3] Epstein, E., Taylor, J.M. and Chaney, R.L. (1976) Effects of sewage sludge and sludge compost applied to soils on some physical and chemical properties. Journal of Environmental Quality, 5, 422-426. doi:10.2134/jeq1976.00472425000500040021x

[4] Smith, S.R. (1996) Agricultural recycling of sewage sludge and the environment. CAB International. Wallingford, 382 .

[5] Kim, K.-R., Owens, G. and Naidu, R. (2009) Heavy metal distribution, bioaccessibility and phytoavailability in longterm contaminated soils from Lake Macquarie. Australian Journal of Soil Research, 47, 166-176. doi:10.1071/SR08054

[6] Nicholson, F.A., Chambers, B.J. and Alloway, B.J. (1997) Effect of soil $\mathrm{pH}$ on heavy metal bioavailability. Proceeding of Fourth International Conference on the Biogeochemistry of Trace Elements, Berkeley, 23-26 June 1997, 499-500.

[7] Zhao, F.J., Dunham, S.J. and McGrath, S.P. (1997) Lessons to be learned about soil-plant metal transfers from the 50-year sewage sludge experiment at Woburn, UK. Fourth International Conference on the Biogeochemistry of Trace Elements, Berkeley, 23-26 June 1997, 693-694.

[8] Horn, A.L., Düring, R.-A. and Gäth, S. (2003) Comparison of decision support systems for an optimised application of compost and sewage sludge on agricultural land based on heavy metal accumulation in soil. Science of the Total Environment, 311, 35-48.

doi:10.1016/S0048-9697(03)00133-5

[9] Moolenaar, S.W., Lexmond, T.M. and van der Zee, S.E.A.T.M. (1997) Calculating heavy metal accumulation in soil: A comparison of methods illustrated by a casestudy on compost application. Agricultural Ecosystem and Environment, 66, 71-82. doi:10.1016/S0167-8809(97)00087-X

[10] MIFAFF (2012) Fertilizer Management Act 2012. Ministry for Food, Agriculture, Forestry and Fisheries, Seoul.

[11] Nelson, D.W. and Sommers, L.E. (1996) Total carbon, organic carbon, and organic matter. In: Page, A.L., et al. (Eds.), Methods of Soil Analysis, Part 2. Chemical Analysis, 2nd Edition, Soil Science Society of America, Madison, 961-1110.

[12] Bremner, J.M. (1996) Nirogen-total. In: Sparks, D.L., et al. (Eds.), Methods of soil analysis. Part 3. Chemical Methods. SSSA and ASA, Madison, 1085-1121.

[13] Miller, W.P. and Miller, M. (1987) A micro pipette method for soil mechanical analysis. Communications in Soil Science and Plant Analysis, 18, 1-15. doi:10.1080/00103628709367799

[14] Sumner, M.E. and Miller, W.P. (1996) Cation exchange capacity and exchange coefficients. In: Sparks, D.L., et al. Eds., Methods of Soil Analysis Part 3. Chemical Methods, Soil Science Society of America, Madison.

[15] Kim, K.-R., Owens, G. and Naidu, R. (2010) Effect of root-induced chemical changes on dynamics and plant uptake of heavy metals in rhizosphere soils. Pedosphere, 20, 494-504. doi:10.1016/S1002-0160(10)60039-2

[16] MoE (2007) Soil Environment Conservation Act 2007. Ministry of Environment, Seoul.

[17] Chang, A.C., Page, A.L., Warneke, J.E. and Grgurevic, E. (1984) Sequential extraction of heavy metals following a sludge application. Journal of Environmental Quality, 13, 33-38. doi:10.2134/jeq1984.00472425001300010006x

[18] Kim, J.G., Lee, K.B., Lee, S.B., Lee, D.B. and Kim, S.J. (2000) The effect of long-term application of different organic material sources on chemical properties of upland soil. Korean Journal of Soil Science and Fertilizer, 33, 416-431.

[19] Businelli, D., Massaccesi, L., Said-Pullicino, D. and Gigliotti, G. (2009) Long-term distribution, mobility and plant availability of compost-derived heavy metals in a landfill covering soil. Science of the Total Environment, 407, 1426-1435. doi:10.1016/j.scitotenv.2008.10.052

[20] Kim, K.-R., Owens, G., Naidu, R. and Kim, K.-H. (2007) Hyperaccumulation mechanism in plants and the effects of roots on rhizosphere soil chemistry: A critical review. Korean Journal of Soil Science and Fertilizer, 40, 280291.

[21] Jung, G.B., Kim, W.I. and Ryu, I.S. (2000) Fractionation and availability of heavy metals in paddy soils near aban- 
doned mining areas. Korean Journal of Environmental Agriculture, 19, 319-323.

[22] Yoo, S.H., Lee, J.R. and Kim, K.H. (1995) Sequential extraction of $\mathrm{Cd}, \mathrm{Zn}, \mathrm{Cu}$, and $\mathrm{Pb}$ from the polluted paddy soils and their behavior. Korean Journal of Soil Science and Fertilizer, 28, 207-217. 